Utah State University

DigitalCommons@USU

1975

\title{
Production and nitrogen content of herbage in a silverberry (Elaeagnus commutata) community compared to adjacent grassland and forest communities
}

\author{
G.L. Whysong
}

A.W. Bailey

Follow this and additional works at: https://digitalcommons.usu.edu/aspen_bib

Part of the Forest Sciences Commons

\section{Recommended Citation}

Whysong, Gary L.; Bailey, A. W. 1975. Production and nitrogen content of herbage in a silverberry (Elaeagnus commutata) community compared to adjacent grassland and forest communities. Canadian Journal of Plant Science 55: 801-808.

This Article is brought to you for free and open access by the Aspen Research at DigitalCommons@USU. It has been accepted for inclusion in Aspen Bibliography by an authorized administrator of DigitalCommons@USU. For more information, please contact

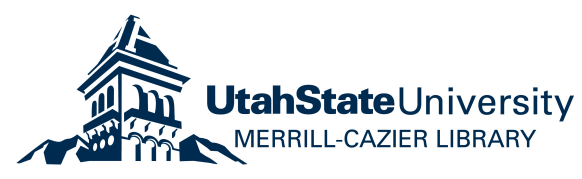




\title{
PRODUCTION AND NITROGEN CONTENT OF HERBAGE IN A SILVERBERRY (ELAEAGNUS COMMUTATA) COMMUNITY COMPARED TO ADJACENT GRASSLAND AND FOREST COMMUNITIES
}

\author{
GARY L. WHYSONG ${ }^{1}$ and ARTHUR W. BAILEY \\ Department of Plant Science, University of Alberta, Edmonton, Alta. T6G 2El. \\ Received 3 Oct. 1974, accepted 15 Apr. 1975.
}

\begin{abstract}
Whysong, Gary L. And Bailey, Arthur W. 1975. Production and nitrogen content of herbage in a silverberry (Elaeagnus commutata) community compared to adjacent grassland and forest communities. Can. J. Plant Sci. 55: 801-808.
\end{abstract}

Production and nitrogen content of herbage growing under the nitrogen-fixing shrub silverberry (Elaeagnus commutata Bernh.) was compared with that in adjacent grassland and aspen poplar (Populus tremuloides Michx.) and balsam poplar (Populus balsamifera L.) forest communities. The soil was an outwash sand over lacustrine clay and a water table was present. The greatest cover and highest production of desirable forage plants, particularly Kentucky bluegrass (Poa pratensis L.), occurred in the silverberry community. The percentage nitrogen in grass and sedge (Carex spp.), forbs and baltic rush (Juncus balticus Willd.) was higher under silverberry than in the grassland. Similar results occurred when the silverberry and poplar communities were compared, with the exception of baltic rush which demonstrated no difference in percentage nitrogen. There was no difference in herbage production between the grassland and silverberry communities, but the change in vegetative composition and the increased nitrogen content made the forage in the silverberry community more desirable for grazing livestock. The shrub silverberry was beneficial to the growth of desirable forages, whereas aspen and balsam poplar in the forest community reduced herbage production by $63 \%$ on these rangelands. Poplar stands growing adjacent to silverberry stands had higher tree production, higher percentage nitrogen in leaves and litter and a greater quantity of nitrogen in above-ground parts than in poplar stands growing a distance away from silverberry.

On a comparé la production végétale et la teneur en $\mathrm{N}$ des herbages poussant sous un couvert de chalef argenté (Elaeagnus commutata Bernh.), arbuste fixateur d'azote, et de ceux poussant dans une prairie ou dans un couvert forestier voisin de peuplier faux-tremble (Populus tremuloides Michx.) et de peuplier baumier (Populus balsamifera L.). Le sol consistait en sable de délavage sur argile lacustre et possédait une nappe phréatique, le couvert le plus abondant et la plus forte production de plantes fourragères utiles, notamment du pâturin du Kentucky ( $P o a$ pratensis L.), ont été obtenus dans la communauté à chalef. La teneur en $\mathrm{N}$ des graminées, des carex, du jonc de la Baltique (Juncus balticus Willd.) et d'autres herbacées a été plus forte sous chalef qu'en prairie. La même comparaison s'applique entre les communautés à chalef et les communautés à peuplier, sauf que le jonc de la Baltique n'a manifesté aucune différence dans ces deux associations. La production d'herbage a été la même en prairie que sous chalef, mais vu le changement de composition botanique et l'accroissement de la teneur en $\mathrm{N}$, les herbages de la communauté à chalef ont eu plus de valeur pour la paissance. Le chalef a favorisé la croissance des plantes fourragères utiles, tandis que les peupliers ont abaissé la production herbagère de $63 \%$. Les peuplements de peupliers

${ }^{1}$ Present address (G.L.W.): Division of Agriculture, Arizona State University, Tempe, Ariz.

Can. J. Plant Sci. 55: 801-808 (July 1975) 
avoisinant ceux de chalef avaient une plus forte production ligneuse, une plus forte teneur en $\mathrm{N}$ des feuilles et de la litière et une plus grande quantité de $\mathrm{N}$ dans les parties aériennes que les peupliers poussant à une certaine distance du chalef.

Woody plants are normally considered deterimental to the understory herbaceous vegetation. The woody plants usually compete vigorously with other plant species in the community for light, moisture, nitrogen and other environmental and edaphic factors necessary for maximum growth. Potential yield of understory forage may be reduced by the effects of associated shrubs and trees (Blaisdell 1949; Johnston and Smoliak 1968; and Robertson 1947). Although the detrimental effects of woody plants on desirable forage species are widely known, the beneficial effects of some are not.

It has been demonstrated under field conditions in the Alberta aspen parkland that silverberry (Elaeagnus commutata Bernh.) is usually not detrimental to the production of associated forage species (Bailey 1970; Corns and Schraa 1965). Subsequent greenhouse studies (Bailey and Gupta 1973) have demonstrated that silverberry contributed some factor, probably nitrogen, that was beneficial to the growth of a forage planted after the shrub had been grown in the soil. Two other woody plants, aspen (Populus tremuloides Michx.) and snowberry (Symphoricarpos occidentalis Hook.) caused a reduction in the growth of the forage planted in the same soil after removal of the woody plants. Bailey (1973) found that nodulated silverberry plants grew better than non-nodulated plants. Recently, Vlassak et al. (1973) demonstrated that silverberry was an important nitrogenfixer in certain mixed prairie grasslands of Saskatchewan.

The objective of the study was to determine the influence of silverberry on vegetation in a shrub-grassland ecosystem compared with a grassland (Juncus balticus Willd. - Poa pratensis L.) and poplar forest (Populus tremuloides and P. balsamifera) ecosystem (Fig. 1). The nitrogen economy of above vegetation was also to be studied.

\section{METHODS}

The study area was on the eastern edge of Beaverhill Lake; $80 \mathrm{~km}$ east of Edmonton, Alberta. Soils were exposed by receding lake waters about $20 \mathrm{yr}$ prior to the study. Nitrogendeficient, coarse-textured outwash sands occurred over lacustrine clay subsoils. The water table generally did not exceed $130 \mathrm{~cm}$ in depth. The surface soil $p \mathrm{H}$ averaged 7.5, with subsoils averaging 8.0. Sodium levels were very high in the lacustrine clay subsoil. Average annual precipitation for Ranfurly, $59 \mathrm{~km}$ east of the study area, was $41 \mathrm{~cm}$ with $22 \mathrm{~cm}$ occurring during the growing season (Environment Canada Atmospheric Environment Service 1972).

Six adjacent stands of grassland, silverberry and poplar forest communities were randomly selected from those available. Large exclosures were constructed in 1972 prior to the study in order to exclude grazing.

In mid-July 1972, canopy coverage of herbaceous species was recorded in 15 randomly located $20 \times 50-\mathrm{cm}$ cover plots per exclosure. Five cover plots were recorded in each stand of a plant community. Canopy cover of woody species was recorded in five $50 \times 100-\mathrm{cm}$ plots in each stand. Production of herbaceous species was measured by clipping the annual growth at ground level in each of the $50 \times 100-\mathrm{cm}$ plots in early August. Clipped herbage was sorted to baltic rush, forbs, grass and sedge, and ovendried. Woody plants were harvested in the silverberry-grassland and poplar communities. One woody stem was randomly selected in each of five $50 \times 200-\mathrm{cm}$ plots per stand, cut down and separated into leaves, annual stems, and old wood. Weight per plot was derived by multiplying stem density $\times$ weight of the stem sampled. Samples for nitrogen analysis were combined into their respective categories for each plant community to form a composite, but were kept separate by exclosures. Each composite sample was thoroughly mixed and percent nitrogen was determined from three subsamples by use of a Coleman Nitrogen Analyzer II, model 29A. Data were analyzed by analysis of variance for a 


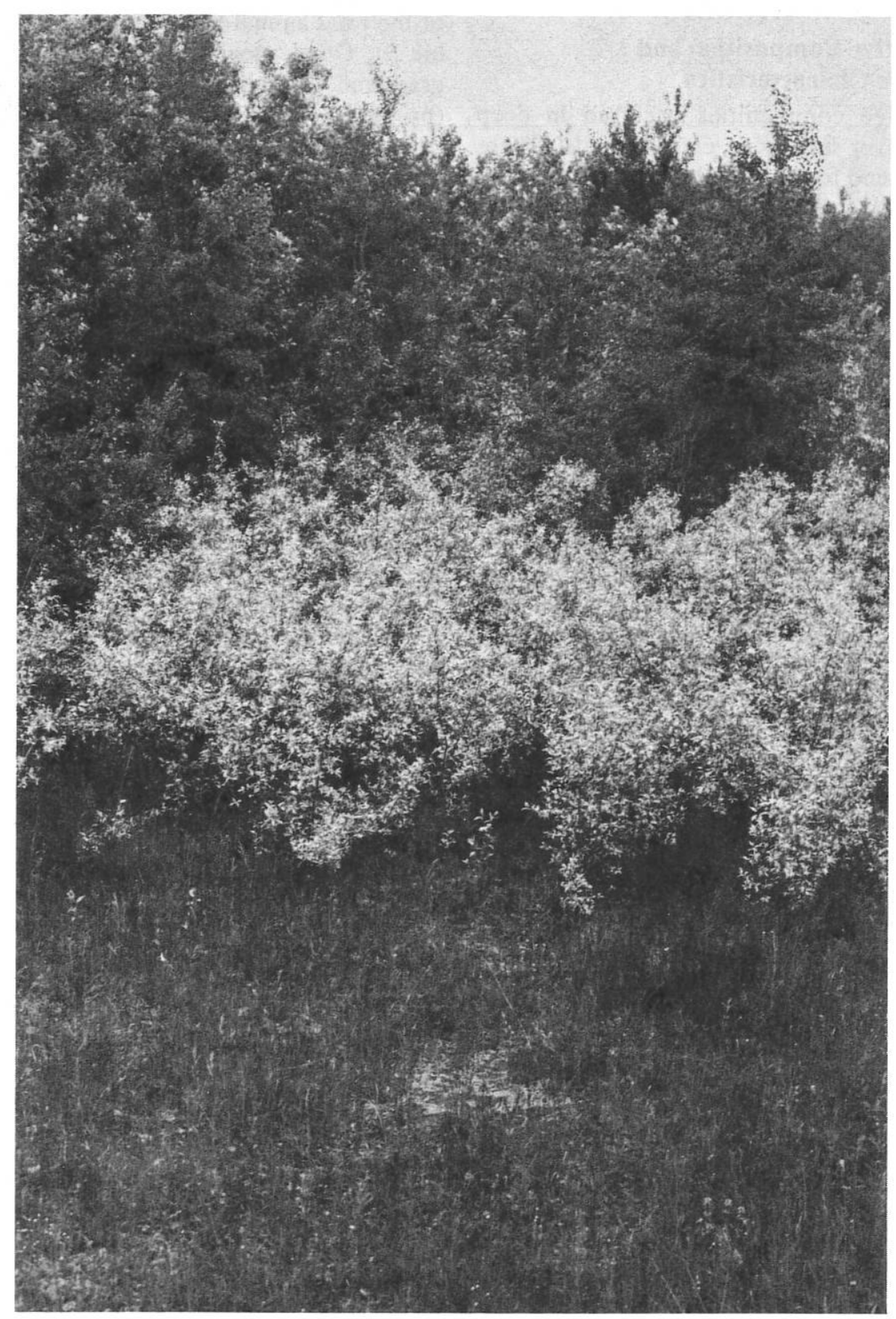

Fig. 1. An example of adjacent stands of the grassland, silverberry and poplar plant communities. 
randomized-block design with subsampling. Percentage values obtained from nitrogen analysis were treated statistically after transformation to $\sqrt{X+0.5}$ (Steel and Torrie 1960).

\section{RESULTS}

Vegetative Composition and Edaphic Characteristics

The three communities occurred in deep sands over lacustrine clay subsoils. There was a trend for the woody stands to grow on soils with shallower depths of sand, but the differences among communities were not significant (Table 1). The poplar community had a thinner layer of organic matter in the $\mathrm{Ah}$ horizon. The $p \mathrm{H}$ of the surface horizon was the same in all communities. The quantity of light available to herbaceous plants differed greatly among the communities. Vegetation in the grassland was exposed to full sunlight. In the silverberry and poplar communities, there was less light available for understory growth.

The grassland and silverberry communities had a high canopy cover of herbaceous plants, while the poplar forest had much less. Both the silverberry and poplar communities had a high cover of woody species (Fig. 1). The silverberry community had the highest total canopy cover, double that of the grassland.

The grassland community was dominated by baltic rush but the $17 \%$ mean canopy cover (Table 2) was an underestimate of the influence of the species in the community.
This was caused by the vertical, single-stem growth habit of baltic rush from an underground rhizome. A more realistic estimate of the influence of baltic rush was given by its herbage production of $659 \mathrm{~kg} / \mathrm{ha}$, or $56 \%$ of the total annual herbage production (Table 3). Other species of importance in the grassland community included bluegrasses (primarily Poa pratensis with some $P$. nervosa (Hook.) Vasey), pussytoes (Antennaria nitida Greene) and wild strawberry (Frageria virginiana Duchesne).

The silverberry community had a shrub layer and a herbaceous layer. The 1.5-m tall silverberry had a mean cover of $64 \%$ and dominated the stands. Age of the oldest stem in each stand ranged from 6 to $19 \mathrm{yr}$. There was a comparatively rich herbaceous understory which had a higher mean canopy cover $(110 \%)$ than the total cover of the grassland. The major understory dominant was Kentucky bluegrass ( $P$. pratensis) and there were lesser amounts of the forbs blue lettuce (Lactuca pulchella (Pursh) DC.) and wild strawberry.

Silverberry plants had nodules on the fine roots in all six stands. Most nodules were found $30-60 \mathrm{~cm}$ below the soil surface.

The poplar forest community was dominated by 3 - to 5-m tall aspen and balsam poplar. Age of the oldest tree in each stand ranged from 10 to $16 \mathrm{yr}$. The understory was sparse, consisting of willow (Salix spp.) with $7 \%$ cover and herbaceous plants with $41 \%$ cover.

Table 1. Selected properties of the plant communities

\begin{tabular}{lrrr}
\hline \hline & \multicolumn{3}{c}{ Plant community } \\
\cline { 2 - 4 } Property & Grassland & Silverberry & Poplar \\
\hline Depth of sand (cm) & $96.6 a^{*}$ & $92.8 a$ & $84.4 a$ \\
Depth of organic matter (cm) & $5.3 a$ & $5.1 a$ & $2.4 b$ \\
$p$ H of Ah horizon & $7.5 a$ & $7.5 a$ & $7.3 a$ \\
Light at $15 \mathrm{~cm}(\mathrm{~lx})$ & $48,977.4 a$ & $20,398.3 b$ & $13,702.9 b$ \\
Total herbaceous cover $(\%)$ & 87 & 110 & 41 \\
Grass and sedge cover $(\%)$ & 18 & 53 & 11 \\
Forbs & 52 & 49 & 85 \\
Woody cover $(\%)$ & 5 & 71 & 126 \\
Total cover $(\%)$ & 92 & 181 & \\
\hline
\end{tabular}

*Means followed by the same letter in horizontal sequence are not significantly different $(P<0.01)$ according to Duncan's multiple range test. 
Table 2. Canopy cover $(\%)$ of species comprising plant groups in the three adjacent plant communities

\begin{tabular}{|c|c|c|c|}
\hline \multirow[b]{2}{*}{ Group and species } & \multicolumn{3}{|c|}{ Plant community } \\
\hline & Grassland & Silverberry & Poplar \\
\hline Baltic rush (Juncus balticus) & 17 & 8 & 11 \\
\hline \multicolumn{4}{|l|}{ Grass and sedge } \\
\hline Bluegrass (Poa spp.) & 13 & 50 & 9 \\
\hline Reedgrass (Calamagrostis spp.) & $*$ & $*$ & 2 \\
\hline Wheatgrass (Agropyron spp.) & 3 & 2 & 1 \\
\hline Smooth brome (Bromus inermis) & 1 & $\mathrm{P}$ & \\
\hline Sedge (Carex spp.) & 1 & $\mathrm{P}$ & \\
\hline \multicolumn{4}{|l|}{ Forbs } \\
\hline Wild strawberry (Frageria virginiana) & 14 & 11 & 5 \\
\hline Yarrow (Achillea millefolium) & 6 & 9 & 2 \\
\hline Blue lettuce (Lactuca pulchella) & 9 & 13 & 1 \\
\hline Dandelion (Taraxacum laevigatum) & 4 & 6 & 5 \\
\hline Pussytoes (Antennaria nitida) & 14 & 4 & 1 \\
\hline Aster (Aster spp.) & 1 & 1 & 3 \\
\hline Other & 5 & 6 & 3 \\
\hline \multicolumn{4}{|l|}{ Woody species } \\
\hline Poplar (Populus spp.) & * & * & 75 \\
\hline Silverberry (Elaeagnus commutata) & 4 & 64 & \\
\hline Snowberry (Symphoricarpos occidentalis) & $\mathrm{P}$ & 1 & * \\
\hline Rose (Rosa woodsii) & * & $*$ & $*$ \\
\hline Bearberry (Arctostaphylos uva-ursi) & & & 2 \\
\hline Willow (Salix spp.) & 1 & 5 & 7 \\
\hline
\end{tabular}

$* P=$ less than $1 \%$ cover.

\section{Herbage and Woody Production}

The grassland and silverberry communities produced nearly three times as much herbage as did the poplar community (Table $3)$. Herbage production was the same in the grassland and silverberry communities. The silverberry community, however, produced twice as much of the palatable Kentucky bluegrass and half as much of the less palatable baltic rush compared with the grassland. Forb production was the same in both communities. The poplar forest community had reduced the herbage production on these rangelands by $63 \%$. There was

Table 3. Production $(\mathrm{kg} / \mathrm{ha})$ in three adjacent plant communities

\begin{tabular}{lrrr}
\hline \hline & \multicolumn{3}{c}{ Plant community } \\
\cline { 2 - 4 } Plant group or part & Grassland & Silverberry & Poplar \\
\hline Baltic rush & $659 a^{*}$ & $356 b$ & $241 c$ \\
Grass and sedge & $304 b$ & $612 a$ & $155 c$ \\
Forbs & $220 a$ & $202 a$ & $46 b$ \\
Woody leaves & $2 c$ & $1,426 b$ & $3,160 a$ \\
Woody annual stems & $1 b$ & $923 a$ & $1,012 a$ \\
Old wood & $2 c$ & $7,269 b$ & $38,350 a$ \\
Total herbaceous & $1,183 a$ & $1,170 a$ & $442 b$ \\
Total woody standing crop & $5 c$ & $9,618 b$ & $42,522 a$ \\
Total standing crop & $1,188 c$ & $10,788 b$ & $42,964 a$ \\
Total herbaceous \& woody leaves & $1,185 c$ & $2,596 b$ & $3,602 a$ \\
Litter & $1,198 c$ & $1,664 b$ & $3,400 a$ \\
& & &
\end{tabular}

*Means followed by the same letter in horizontal sequence are not significantly different $(P<0.05)$ according to Duncan's multiple range test. 
$75 \%$ less grass production under the poplar forest than under silverberry.

The silverberry and poplar communities had a standing crop of woody material of $9,618 \mathrm{~kg} / \mathrm{ha}$ and $42,522 \mathrm{~kg} / \mathrm{ha}$, respectively. Annual production was approximately $1,186,3,519$, and $4,614 \mathrm{~kg} / \mathrm{ha}$ in the grassland, silverberry and poplar communities, respectively.

The quantity of litter was least in the grassland and greatest in the poplar community. Litter production was closely related to the quantity of herbaceous growth and woody leaves in the grassland and poplar communities. There was a much greater production of herbage plus woody leaves than litter in the silverberry community. Perhaps the silverberry leaves were broken down and incorporated into the soil organic layer more quickly than were poplar leaves.

During the planning stages, one of the criteria established for site selection was that stands of the three communities should be adjacent, or at least in close proximity to one another. The objective of this criterion was to reduce the chance that stands be located on different edaphic environments. All silverberry stands were adjacent to grassland stands. Three poplar stands were adjacent to stands of the other two communities. The other poplar stands were $15-30 \mathrm{~m}$ distance from the grassland and silverberry stands. Where a poplar stand was adjacent to grassland and silverberry stands, the poplar appeared to be gradually invading them. One-year-old poplar suckers occurred in all such stands of grassland and silverberry. Marked differences in production were observed. The herbage production in grassland stands located 15-30 $\mathrm{m}$ away from poplar stands averaged 1,458 $\mathrm{kg} / \mathrm{ha}$ compared to $913 \mathrm{~kg} / \mathrm{ha}$ in grasslands located adjacent to poplar stands. Marked differences in production of woody parts were also noticed in poplar stands (Table 4). Although the number of replications was not sufficient to justify statistical treatment of these data, poplar stands lo- cated near silverberry had a higher production than did stands separated from silverberry.

\section{Nitrogen Content}

All nitrogen measurements were within $1 \%$ among subsamples. Nitrogen content of grass, sedge, forbs and baltic rush was greatest in the silverberry community (Table 5). Unlike the grassland and silverberry areas, differences did exist in the nitrogen content of baltic rush and grass and sedges in the poplar. Forbs growing under silverberry contained the highest level of nitrogen of all plant groups.

The quantity of nitrogen contained in herbage was highest in the silverberry, intermediate in the grassland and lowest in the poplar community. Baltic rush contained more of the total nitrogen in the grassland and poplar areas, while grass and sedge, the most desirable forage, contained half the nitrogen in the silverberry community. There was three times more nitrogen by weight in grass and sedge in the silverberry community than in the grassland.

The nitrogen content (\%) of woody parts in the silverberry community was usually higher than in the poplar community (Table 6 ). Leaves had the highest nitrogen content, while the old wood had the lowest. Where poplar stands were near silverberry stands, the nitrogen content (\%) and quantity of nitrogen $(\mathrm{kg} / \mathrm{ha})$ of litter and poplar leaves

Table 4. Production of woody parts $(\mathrm{kg} / \mathrm{ha})$ in the silverberry community and in poplar stands near and far from silverberry stands

\begin{tabular}{lrrr}
\hline \hline & \multicolumn{3}{c}{ Plant community } \\
\cline { 2 - 4 } Plant & \multicolumn{3}{c}{ Poplar } \\
\cline { 2 - 4 } part & $\begin{array}{c}\text { Silver- } \\
\text { berry }\end{array}$ & Near & \multicolumn{1}{c}{ Far } \\
\cline { 3 - 4 } $\begin{array}{l}\text { Leaves } \\
\text { Annual }\end{array}$ & 1,426 & 3,970 & 2,340 \\
$\quad$ stems & 923 & 1,120 & 910 \\
Old wood & 7,269 & 45,020 & 31,680 \\
Total & 9,618 & 50,110 & 34,930 \\
\hline
\end{tabular}


Table 5. Nitrogen content and quantity of total nitrogen contained in herbage and litter from three adjacent plant communities

\begin{tabular}{lccc}
\hline \hline & \multicolumn{3}{c}{ Plant community } \\
\cline { 2 - 4 } Plant group & Grassland & Silverberry & Poplar \\
\hline Nitrogen content (\%) & & & \\
$\quad$ Baltic rush & $0.94 b^{*}$ & $1.23 a$ & $1.12 a$ \\
Grass and sedge & $0.91 b$ & $1.23 a$ & $1.88 b$ \\
Forbs & $1.34 b$ & $1.76 a$ & $1.23 b$ \\
$\quad$ Litter & $0.91 c$ & $1.51 a$ & $2.7 b$ \\
Total nitrogen (kg/ha) & & & $1.4 c$ \\
$\quad$ Baltic rush & $6.2 a$ & $4.4 a$ & $0.6 b$ \\
Grass and sedge & $2.8 b$ & $3.5 a$ & $4.7 c$ \\
$\quad$ Forbs & $3.0 a$ & $15.5 a$ & $42.8 a$ \\
Herbage nitrogen & $12.0 b$ & $25.5 b$ & \\
Litter & $11.3 c$ & & \\
\hline
\end{tabular}

* Means followed by the same letter in horizontal sequence are not significantly different $(P<0.05)$ according to Duncan's multiple range test.

was higher than where poplar stands were a distance from silverberry stands.

Silverberry contributed significant amounts of nitrogen to the shrub and forest ecosystems (Fig. 2). There were greater amounts of nitrogen in the herbage, standing crop, litter and tree and shrub leaves when silverberry was present as compared to adjacent grassland communities and to poplar communities located a distance away from silverberry.

\section{DISCUSSION}

Woody plants are not always detrimental to the growth of understory herbaceous plants. The presence of silverberry in the grassland studied was beneficial. This was because of the change in understory dominance to a forage species more preferred by cattle without a reduction in herbage yield. There was also an increased nitrogen content of the herbage. It was also observed that grasses remained greener and more succulent under

Table 6. Nitrogen content and quantity of total nitrogen in woody plants and litter of the silverberry community and in poplar stands near to and far from silverberry stands

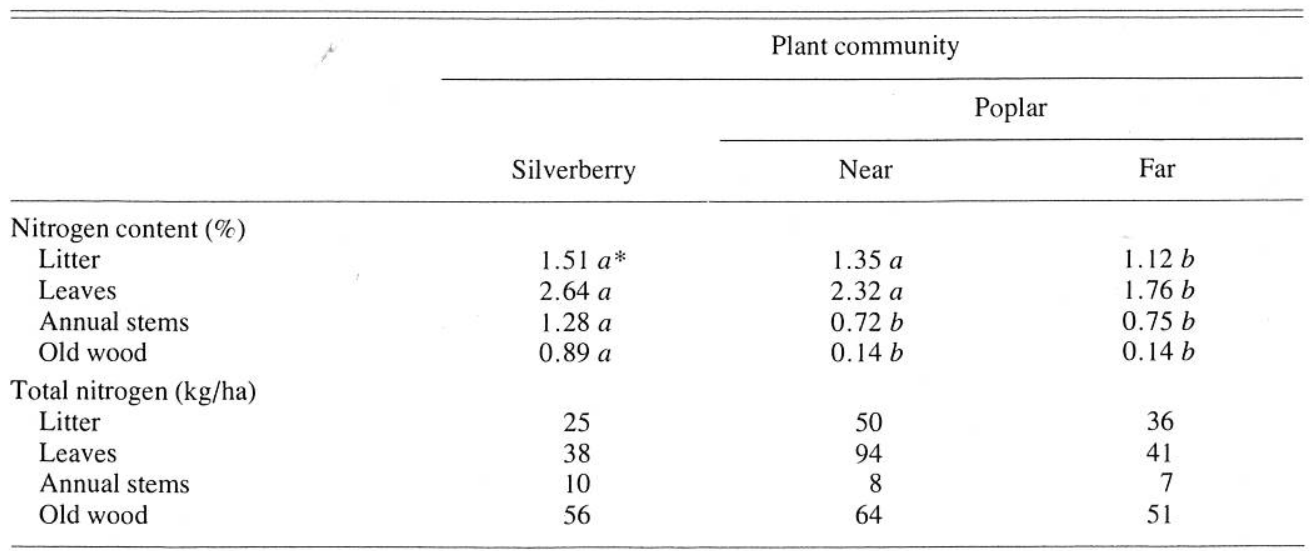

*Means followed by the same letter in horizontal sequence are not significantly different $(P<0.05)$ according to Duncan's multiple range test. 


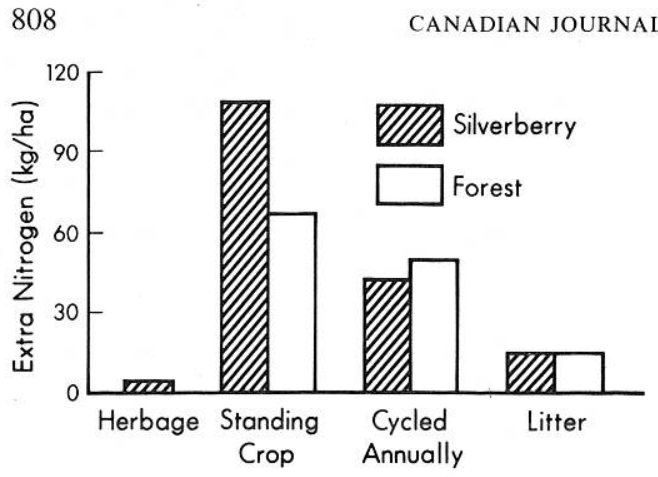

Fig. 2. Nitrogen added to the above-ground parts of two plant communities by silverberry.

silverberry than in adjacent grassland. Hilton and Bailey (1972) showed that forage with a higher moisture content in July and August was more preferred by cattle. In spite of the barrier effect of the shrub when present in the grassland (Bailey 1970), cattle have been observed grazing understory vegetation of silverberry communities in preference to grazing baltic rush and grasses in adjacent grasslands in the parkland region.

Poplar utilized not only the soil it grew on but also the soil underlying surrounding communities. One-year-old poplar suckers and poplar roots were common in grassland and silverberry stands for a distance of at least $10 \mathrm{~m}$ from the parent clone. The presence of an adjacent poplar stand reduced production in the grassland by an average of $37 \%$. The reduced herbage production was presumably caused by poplar through competition for moisture and nutrients. Where there was competition for light as well as moisture and nutrients as under the poplar stands, herbage production was reduced by $63 \%$. The influence of the poplar trees on understory vegetation was very great.

Production in the silverberry stands adjacent to poplar stands was not reduced, but the poplars benefited. The standing crop of woody material in poplar stands near silverberry averaged $15,180 \mathrm{~kg} / \mathrm{ha}$ more than in poplar stands a distance away from silverberry. There was an extra $81 \mathrm{~kg} / \mathrm{ha}$ of nitrogen in above-ground parts and litter in poplar stands adjacent to silverberry.
Vlassak et al. (1973) found silverberry to be an important nitrogen-fixer in certain Dark Brown soils of Saskatchewan. On the subirrigated sands under study, silverberry was also found to be an important nitrogen-fixer.

\section{ACKNOWLEDGMENT}

The research was supported by the National Research Council of Canada grant number A-4338 to the junior author. The Soil and Feed Testing Laboratory, Alberta Department of Agriculture, analyzed the soil samples.

BAILEY, A. W. 1970. Barrier effect of the shrub Elaeagnus commutata on grazing cattle and forage production in central Alberta. J. Range Manage 23: 248-251.

BAILEY, A. W. 1973. Effects of nodulation on growth of silverberry. Can. J. Plant Sci. 53: 919-920.

BAILEY, A. W. and GUPTA, R. K. 1973. Grass-woody plant relationships. Can. J. Plant Sci. 53: 671-676.

BLAISDELL, J. P. 1949. Competition between sagebrush seedlings and reseeded grasses. Ecology 30: 512-519.

CORNS, W. G. and SCHRAA, R. J. 1965. Mechanical and chemical control of silverberry (Elaeagnus commutata Bernh.) on native grassland. J. Range Manage.18: 15-19.

ENVIRONMENT CANADA ATMOSPHERIC ENVIRONMENT SERVICE. 1972. Monthly record meteorological observations in Canada. Downsview, Ont.

JOHNSTON, A. and SMOKIAK, S. 1968. Reclaiming brushland in southwestern Alberta. J. Range Manage. 21: 404-406.

HILTON, J. E. and BAILEY, A. W. 1972. Cattle use of a sprayed aspen parkland range. J. Range Manage. 25: 257-260.

ROBERTSON, J. H. 1947. Responses of range grasses to different intensities of competition with sagebrush (Artemisia tridentata Nutt.) Ecology 28: 1-16.

STEEL, R. G. D. and TORRIE, J. H. 1960. Principles and procedures of statistics. McGraw-Hill Book Co. Inc., New York, Toronto, London. 481 pp.

VLASSAK, K., PAUL, E. A. and HARRIS, R. E. 1973. Assessment of biological nitrogen fixation in grassland and associated sites. Plant and Soil 38: 637-649. 